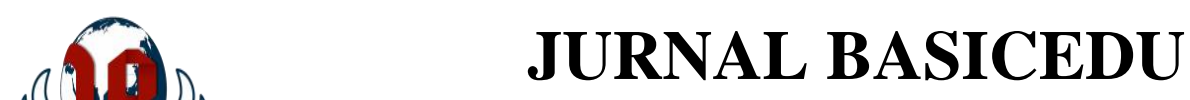

Volume 5 Nomor 4 Tahun 2021 Halaman 2377 - 2383

Research \& Learning in Elementary Education https://jbasic.org/index.php/basicedu

PAHLAWAN

\title{
Pengaruh Model Project Based Learning Berbantuan Google Meet terhadap Kemampuan Berpikir Kreatif Siswa
}

\author{
Aniswati Nahdiah $^{1 凶}$, Sri Lestari Handayani \\ Universitas Muhammadiyah Prof. Dr. Hamka, Indonesia ${ }^{1,2}$ \\ E-mail: anisnahdiah14@gmail.com ${ }^{1}, \underline{\text { srilestarih@uhamka.ac.id }}^{2}$
}

\begin{abstract}
Abstrak
Daya mampu pemikiran kreatifnya, merupakan kemampuannya yang dapat dengan perolehan yang menjadi idenya atau menciptakan suatu produk. Melihat kondisi pembelajaran jarak jauh saat ini banyak sekali kendala, salah satunya pada model pembelajaran. Sehingga rasanya sukar sekali pada perkembangan kemampuan pemikiran dengan kajian project based learning pada daya mampu pemikiran peserta didiknya dengan pemateri ekosistem dengan aplikasi google meet. Penelitian kuantitatif ini menggunakaan metode penelitian kuasi eksperimen. Rancangan desain yang digunakan ialah the non-equivalent design. Penelitian ini dilakukan pada SD Negeri Pinang Ranti 01. Populasi dari penelitian ini adalah kelas V sebanyak 60 siswa. Sampel yang diambil terdiri dari 30 siswa kelas VA dan 30 siswa kelas VB. Tekniknya dipergunakan dari kajian yaitu tes tertulis data dokumentasi. Tekniknya dengan kajian menggunakan uji t dengan taraf signifikansi sebesar 0,05 berbantuan SPSS versi 25. Hasilnya memperlihatkan jika memengaruhi pada daya mampu pemikirannya.
\end{abstract}

Kata Kunci: kemampuan berpikir kreatif, project based learning, ekosistem.

\begin{abstract}
Creative thinking is an ability that can generate an idea or create a product. In these current conditions, there are many obstacles to distance learning, one of which is the learning model method. So that this condition becomes difficult to develop students' creative thinking skills. This study aims to determine the effect of the project-based learning model on the creative thinking skills of fifth-grade students on ecosystem materials using the google meet the application. This quantitative research uses quasi-experimental research methods. The design that is being used is a non-equivalent design. This research was conducted at the Primary School of Pinang Ranti 01. The population of this study was 60 students of fifth grade. The sample consisted of 30 students in-class VA and 30 students in class VB. The data collection techniques used in this study are written tests and documentation. The data analysis technique in this study used a t-test with a significance level (0.05) with SPSS version 25. The results of this study show that there is an influence of project-based learning on student's creative thinking skills of ecosystem materials.
\end{abstract}

Keywords: creative thinking skill, project-based learning, ecosystem.

Copyright (c) 2021 Aniswati Nahdiah, Sri Lestari Handayani

Corresponding author :

Email : anisnahdiah14@gmail.com

DOI : https://doi.org/10.31004/basicedu.v5i4.1228

ISSN 2580-3735 (Media Cetak)

ISSN 2580-1147 (Media Online) 
2378 Pengaruh Model Project Based Learning Berbantuan Google Meet terhadap Kemampuan Berpikir Kreatif Siswa - Aniswati Nahdiah, Sri Lestari Handayani

DOI: https://doi.org/10.31004/basicedu.v5i4.1228

\section{PENDAHULUAN}

Muatan Ilmu Pengetahuan Alam di Sekolah Dasar memiliki tujuan untuk menumbuhkan dan peningkatan daya mampu dari pesertanya, interaktif, kontekstual dan kolaboratif. Dalam dunia pendidikan Sekolah Dasar, perkembangan keterampilan sangat dituntut untuk meningkatkan mutu pendidikan. Media perkembangan, pemikiran dengan memecahkan masalah dan menemukan sebuah gagasan baru terutama dalam muatan Ilmu Pengetahuan Alam. Tanpa adanya keterampilan, seorang siswa tidak dapat mewujudkan idenya untuk membuat karya. Selanjutnya, agar karyanya ingin dihargai, maka peserta didik harus memiliki sikap yang dapat diterima oleh orang lain (Sani, 2019:106).

Akan tetapi melihat kondisi pembelajarannya yang bedampak, pertama kali ditemukan di China menyebabkan diberlakukannya kebijakan bekerja dari rumah, sehingga semua jenjang pendidikan dari dasar sampai dengan yang tinggi pun harus melaksanakan pembelajaran daring dalam rangka pencegahan penyebaran virus Covid-19 (Haryadi \& Selviani, 2021:2). Pada pembelajaran jarak jauh, berdasarkan pengamatan serta fakta yang peneliti ketahui, ada saja guru yang hanya memberikan tugas/PR kepada siswa, seperti mengerjakan soal-soal yang ada di buku atau mengerjakan soal yang dibuat oleh guru itu sendiri. Kemudian pesertanya juga sukar paham suatu yang disebabkan dengan ketepatan di masa pandemi ini. Sehingga rasanya sukar sekali untuk mengembangkan kemampuan berpikir kreatif siswa. Padahal siswa memerlukan kemampuan atau keterampilan dalam menemukan ide serta memecahkan suatu permasalahan.

Keterampilan ialah daya mampu yang dipunyai untuk penyelesaian pekerjaannya dalam suatu kegiatan (Ahmad, 2017:3; Ningsih, 2014:3). Menurut Ningsih (2014:3), anak perlu dilatih keterampilannya sejak dini agar anak dapat tumbuh menjadi orang yang cekatan dan terampil di dalam setiap kegiatannya, dan dapat menghadapi setiap permasalahan dalam hidupnya di masa yang akan datang. Menurut Sudarto (2016:4), keterampilan ada yang bersifat fisik maupun non fisik, yang dikatakan keterampilan bersifat fisik ialah keterampilan seperti keahlian seseorang dalam mengerjakan suatu pekerjaan yang menggunakan beberapa atau seluruh anggota tubuhnya, misalnya memasak makanan, membangun rumah dan sebagainya. Selain itu, keterampilan yang dikatakan non fisik atau keterampilan yang menggunakan keahliannya dalam berpikir, misalnya menyusun sebuah karya ilmiah.

Keterampilan berpiki kreatif merupakan salah satu dari keterampilan berpikir kreatif tingkat tinggi. Kusadi dkk, (2020:2) memaparkan bahwa berpikir kreatif ialah hasil belajar dari konsep dan penerapan, yang dilihat dari keaslian, kelancaran, kelenturan, elaborasi, penilaian serta kemandirian dalam pembelajaran. Berpikir kreatif merupakan kemampuan berpikir yang dilatih secara terus menerus dengan memperhatikan naluri, meningkatkan imajinasi dan ide-ide yang menarik (Ananda, 2019:4). Berpikir kreatif adalah kemampuan seseorang yang didapatkan atau berdasarkan suatu informasi untuk menghasilkan suatu ide baru, baik berupa karya nyata maupun pemikiran yang berbeda dengan ide sebelumnya (Hikmah \& Agustin, 2018:3). Dalam buku Sani (2019:9), kriteria utama dari keterampilan berpikir kreatif adalah kelancaran berpikir (fluency), fleksibilitas berpikir (flexibility) dan orisinalitas (original thinking). Sani (2019:9) menambahkan bahwa, ada dua tes TTCT (Torrance Test of Creative Thinking) berdasarkan teori Guilford, yaitu tes verbal dan tes figural. Dalam tes figural inilah terdapat penambahan ciri, yaitu elaborasi.

Survei yang dilakukan oleh "OECD (Organisation for Economic Co-operation and Development) menunjukkan bahwa hasil PISA (Programme for International Students Assessment) pada tahun 2018, keterampilan sains di Indonesia berada di bawah rata-rata yaitu dengan perolehan skor 396 (Hewi \& Shaleh, 2020:6). Padahal ditahun 2015, hasil PISA menunjukkan bahwa skor rata-rata keterampilan sains di Indonesia yaitu sebesar 403" (Pratiwi, 2019:8). Dengan demikian, perolehan skor rata-rata keterampilan sains peserta didik di Indonesia menurun.

Jalan keluar dari berbagai permasalahan yang telah diuraikan diatas, yakni pemilihan yang menjadi modelnya, kemudian dnegan kepada pembelajaran berpusat pada siswa. Pada project based learning, siswa 
diminta untuk membuat dan menyelesaikan suatu proyek yang nanti akan menghasilkan suatu produk dari ide yang mereka dapat (Nugraha dkk, 2018:2). Selanjutnya, pembelajaran bebasis proyek dapat menumbuh kembangkan pengetahuan, sikap, dan keterampilan peserta didik seperti kreativitas, motivasi, minat, tanggung jawab, kerjasama, bersosialisasi, dan mampu memecahkan masalahnya sendiri (Nuryati dkk, 2020:3). Model project based learning, seperti siswa bekerja di dunia nyata, dan meminta mereka untuk menciptakan suatu produk yang bermanfaat (Putri dkk, 2021:3).

Di Indonesia, pembelajaran berbasis proyek pertama kali di terapkan di sekolah-sekolah kejuruan atau Sekolah Mengah Kejuruan (SMK), akan tetapi pada akhirnya banyak sekali penelitian mendapatkan fakta bahwasannya PjBL tidak hanya berfokus pada penyelesain masalah yang berhubungan dengan ekonomi dan kewirausahaan saja, tetapi juga dapat meningkatkan prestasi peserta didik, motivasi, kreativitas, keterampilan dan sikap. Model pembelajaran ini sangat berpotensi besar bagi peserta didik untuk mendapatkan pengalaman belajar yang menyenangkan dan bermakna (Sumarni, 2015:2). Secara umum, pembelajaran berbasis proyek terdiri dari 6 tahapan di dalam buku Sitorus \& Harahap (2019:80), yaitu “menentuan pertanyaan mendasar (start with the essential question), mendesain perencanaan proyek (design a plan for the project), menyusun jadwal (create a schedule), memonitoring peserta didik dan kemajuan proyek (monitor the students and the progress of the project), menguji hasil (assess the outcome) dan mengevaluasi pengalaman (evaluate the experience)".

Pada pembelajaran berbasis proyek, produk atau karya yang dikerjakan dapat membuat siswa secara tidak langsung menemukan solusi atas masalah yang mereka hadapi dengan cara apapun dan dengan prosedur atau urutan yang mereka inginkan. Selain itu, pembelajaran ini dapat membantu siswa menumbuhkan kreativitas, minat dan bakat. Melalui proses pembelajaran yang interaktif, kontektual serta kolaboratif antara siswa dengan guru sehingga kemampuan berpikir kreatif siswa akan berkembang. Pembelajaran Project Based Learning dapat dilakukan di dua kondisi, yaitu saat dipelajarinya tahapannya.

Pada pembelajaran jarak jauh, guru dan siswa membutuhkan teknologi infomasi yang memumpuni agar pembelajaran tetap belangsung, salah satu contohnya adalah "google meet. Google meet adalah sebuah aplikasi video conference yang digunakan dalam proses meeting secara online yang dibuat dan dikembangkan oleh perusahaan besar bernama Google, sehingga memudahkan proses pembelajaran secara daring (Juniartini \& Rasna, 2020:2; Wiratama, 2020:3). Google meet ini merupakan versi yang di kembangkan dari versi sebelumnya yaitu google hangouts yang dikhususkan untuk bisnis dari semua ukuran" (Rustaman, 2020:3).

Menurut penelitian yang dilakukan oleh Lailiya dan Ririn, terbukti adanya pengaruh model PjBL yang signifikan pada daya mampu dan kreatifitasnya, pengujian dari "uji analisis paired $t$-test yakni nilai (sig.) lebih kecil dari 0,05 (sig. $<0,05$ ) yaitu 0,000 . Sehingga $\mathrm{H}_{0}$ ditolak dan $\mathrm{H}_{1}$ diterima, yang artinya penggunaan model project based learning lebih baik dalam meningkatkan kemampuan berpikir kreatif siswa" (Hikmah \& Agustin, 2018:6). Hal yang membedakan kajian Lailiya dan Ririn yaitu pada populasi, sampel dan materi ajar. Berdasarkan permasalahan-permasalahan dengan penguraiannya, maksud kajian melihat yang memengaruhi variabel.

\section{METODE}

Penelitian ini dilakukan pada Sekolah Dasar Negeri Pinang Ranti 01. Penelitian kuantitatif mempergunakan kajian dengan apa yang akan dilakukan the non-equivalent design. Berikut gambar 1 merupakan rancangan the non-equivalent design (Ismail, 2018:59)

$$
\begin{array}{|ccc|}
O_{1} & \mathrm{X} & O_{2} \\
O_{3} & O_{4}
\end{array}
$$

Gambar 1. The non-equivalent design 
2380 Pengaruh Model Project Based Learning Berbantuan Google Meet terhadap Kemampuan Berpikir Kreatif Siswa - Aniswati Nahdiah, Sri Lestari Handayani

DOI: https://doi.org/10.31004/basicedu.v5i4.1228

"Keterangan

$O_{1}:$ Pre-test kelompok eksperimen.

$\mathrm{O}_{2}:$ Post-test kelompok eksperimen.

$\mathrm{O}_{3}$ : Pre-test kelompok kontrol.

$\mathrm{O}_{4}$ : Post-test kelompok kontrol.

$\mathrm{X}$ : Perlakuan pada kelompok eksperimen".

Populasi yang menjadi target dari penelitian ini adalah kelas V SD Negeri Pinang Ranti 01 Pagi, yakni kelas VA dan kelas VB sebanyak 60 siswa. Dalam kajian ini kelas VA ialah yang mengontrol sedangkan kelas VB ialah yang menjadi percobaan, memakai teknik non-probabilitas sampling dengan metode jenuh. Sampel didalam penelitian ini berjumlah 30 di kelas VA dan 30 siswa di kelas VB.

Jenis instrumen yang digunakan pada penelitian ini adalah tes tertulis dan dokumentasi. Tes tertulis dalam penelitian ini melihat pada indikator kemampuan berpikir kreatif. Sebelumnya, instrumen tes melewati pengujian validitas dan reliabilitas. Uji validitas dipergunakan pada penelitian dengan rumus hubungan menggunakan rumus cronbach alpha.

Tekniknya dari penganalisaan datanya dari kajian ini dengan kuantitatif, kemudian penggambaran data yang didapat berasal dari beberapa hal yang mendukung, pada statistik data yang didapat. Sebelum melakukan perhitungan statistik inferensial, ada persyaratan pengujian analisis, yakni "uji normalitas. Pada pengujian normalitas, data yang diuji menggunakan uji liliefors atau kolmogorov-smirnov pada SPPS. Setelah dilakukan uji persyaratan, dilanjutkan dengan melakukan perhitungan uji hipotesis dengan uji t, yaitu independent t-test menggunakan rumus separated varians. Pada penelitian ini, peneliti menggunakan bantuan SPSS versi 25 untuk melakukan perhitungan".

\section{HASIL DAN PEMBAHASAN}

Hasil dari analisis deskriptif statistik pada data kajiannya, dengan terampil pada pemikirannya perhatiannya pada pemaparan dibawah.

Tabel 1

Statistik Deskriptif Keterampilan Berpikir Kreatif Pretest Posttest Kontrol dan Eksperimen

\begin{tabular}{lccccc} 
& N & $\begin{array}{c}\text { Nilai } \\
\text { Minimum }\end{array}$ & $\begin{array}{c}\text { Nilai } \\
\text { Maksimum }\end{array}$ & Rata-Rata & $\begin{array}{c}\text { Simpangan } \\
\text { Baku }\end{array}$ \\
\hline Pre-tes Eks & 30 & 42 & 71 & 59.80 & 8.177 \\
\hline Post-tes Eks & 30 & 72 & 95 & 84.70 & 6.808 \\
\hline Pre-test Kontrol & 30 & 50 & 71 & 60.70 & 6.686 \\
\hline Post-tes Kontrol & 30 & 60 & 82 & 69.93 & 6.034 \\
\hline
\end{tabular}

Berdasarkan hasil tabel 1 dari data diatas, nilai maksimum pretest kelas eksperimen yang sangat rendah dari nilai maksimum posttest kelas eksperimen, yakni skor maksimum pretest sebesar 71, sedangkan skor maksimum posttest sebesar 95. Apabila dilihat dari kelas kontrol, skor teringgi pretest sebesar 71 dan skor tertinggi posttest sebesar 82 . Selanjutnya, nilai rata-rata kelas eksperimen mempunyai rata-rata pretest 59,80 dan rata-rata nilai posttest 84,70 . Pada kelas kontrol, rata-rata pretest adalah 60.70 , sedangkang rata-rata posttest adalah 69.93. Dapat diperhatikan jika menunjukan bahwa terdapat perbedaan pada nilai data yang diperoleh dari posttest kelas eksperimen ataupun pretest posttest kelas kontrol. Akan tetapi, jika dilihat dari posttest kelas eksperimen yang menggunakan model pembelajaran berbasis proyek, nilai yang diperoleh dengan tingginya eksperimen ataupun pretest posttest kelas kontrol.

Pada pengujian persyaratan, yakni uji normalitas dengan menggunakan uji liliefors pelaksanaan dengan melihat kajian dari tabel 2. 
2381 Pengaruh Model Project Based Learning Berbantuan Google Meet terhadap Kemampuan Berpikir Kreatif Siswa - Aniswati Nahdiah, Sri Lestari Handayani

DOI: https://doi.org/10.31004/basicedu.v5i4.1228

Tabel 2

Uji Normalitas Kelas Eksperimen dan Kelas Kontrol

\begin{tabular}{|c|c|c|c|c|}
\hline Kelas & $\mathbf{N}$ & Lhitung & $\mathbf{L}_{\text {tabel }}$ & Keterangan \\
\hline Pretest Eks & \multirow{4}{*}{30} & 0,0854 & \multirow{4}{*}{0,1614} & \multirow{4}{*}{$\begin{array}{c}\text { Data Berdistribusi } \\
\text { Normal }\end{array}$} \\
\hline Posttest Eks & & 0,149 & & \\
\hline Pretest Kontrol & & 0,158 & & \\
\hline Posttest Kontrol & & 0,109 & & \\
\hline
\end{tabular}

Berdasarkan hasil perhitungan uji normalitas dengan taraf signifikansi $(\alpha)=5 \%$ atau 0,05 diatas, dapat dilihat bahwa $\mathrm{L}_{\text {hitung }}$ pada pretest kelas eksperimen adalah 0,854 , sedangkan $\mathrm{L}_{\text {hitung }}$ pada posttest kelas eksperimen yakni 0,149 . Jika melihat dari hasil pretest kelas kontrol $\mathrm{L}_{\text {hitung }}=0,158$, sedangkan hasil perhitungan pada kelas kontrol menunjukkan bahwa $\mathrm{L}_{\text {hitung }}=0,109$. Dengan demikian, pretest posttest kelas eksperimen yang menggunakan project based learning dan kelas kontrol dengan $\mathrm{L}_{\text {tabel }}=0,1614$ menunjukkan bahwa data berdistribusi normal, dikarenakan seluruh hasil $\mathrm{L}_{\text {hitung }}<\mathrm{L}_{\text {tabel }}$.

Di tahapan selanjutnya, setelah pengujian persyaratan analisis serta perhitungan data pernyataan normalnya ataupun homogen, dengan fase untuk menguji pelaksanaannya dengan tujuan melihat yang memengaruhi dari penggunaan modelnya dengan kemampuan pemikiran, taraf signfikansi $5 \%$ atau 0,05 . Dibawah ini yaitu perhitungan uji t pada tabel 4 berbantuan SPSS versi 25.

Tabel 4

Hasil Uji-t

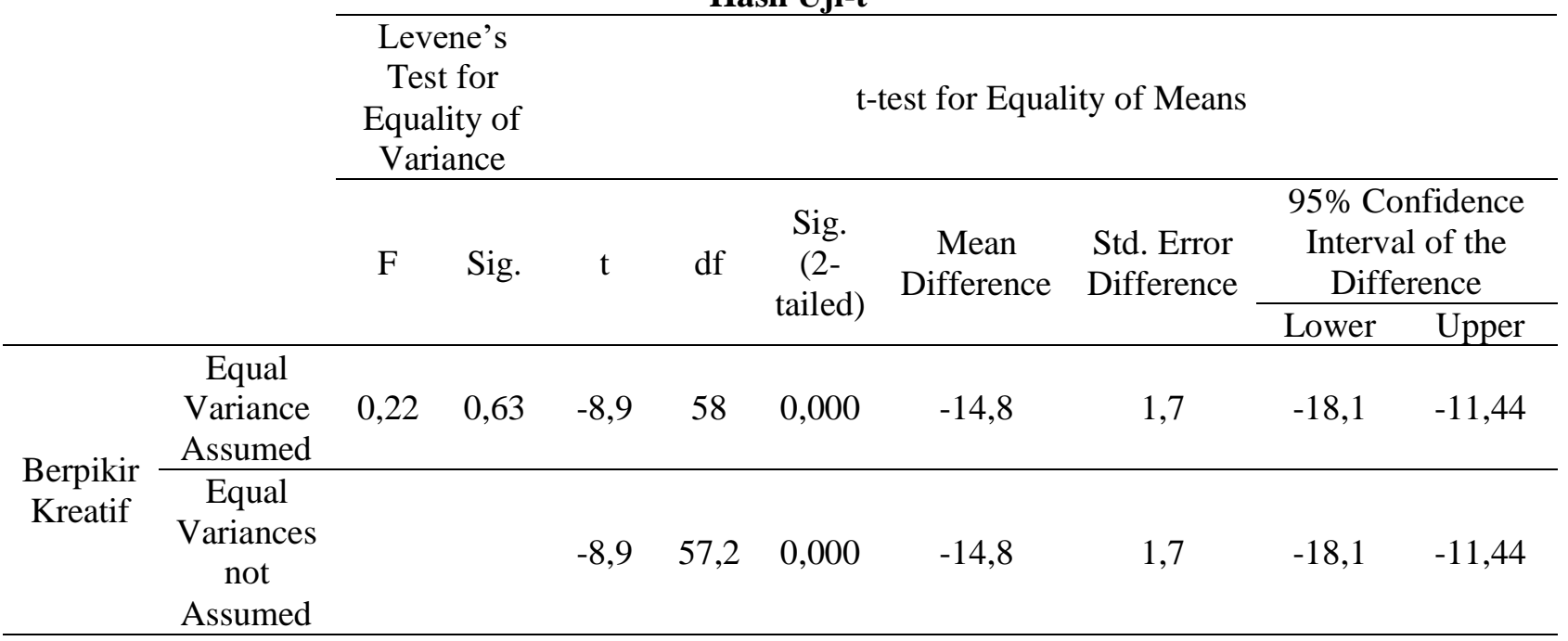

Berdasarkan hasil perhitungan uji independent $t$-test berbantuan SPSS versi 25, apabila dilihat dari kaidah keputusan yaitu nilai signifikan (2-tailed) $<0,05$ dengan pernyataan jika yang memengaruhi apabila dilihat dari hasil perhitungan pada tabel 4 diatas, "signifikan lebih kecil dari 0,05 yakni 0,000 $<0,05$. Dengan demikian, dapat dinyatakan bahwa terdapat pengaruh model project based learning terhadap kemampuan berpikir kreatif siswa materi ekosistem kelas V SD Negeri Pinang Ranti 01".

Berdasarkan hasil serta uraian diatas, jelas bahwa penggunaan model project based learning kemampuan peningakan dengan sebab pada kegiatan berpusat pada siswa untuk menyelesaikan suatu permasalah. Dalam model project based learning, siswa tidak hanya mendengarkan dan memperhatikan tetapi juga terlibat langsung dalam pembelajaran. Model ini mampu meningkatkan kemampuan siswa dengan melibatkan mereka untuk membuat atau menciptakan suatu ide yang berupa karya/produk, sehingga membantu siswa memahami suatu materi (Mawardi \& Sari, 2019:4). Proyek pada model pembelajaran ini berasal dari kumpulan ide siswa sebagai cara lain dalam memecahkan suatu permasalahan yang nyata, sehingga siswa dapat terjun langsung ke dalam proses pembelajaran (Sari dkk., 2019:4). Berbeda dengan pembelajaran yang menggunakan model konvensional, siswa dengan pembatasan memperhatikan suatu diperoleh. 
Kelebihan dalam menggunakan model PjBL (Sitorus \& Harahap, 2019:78), antara lain: “(1) meningkatkan keterampilan peserta didik; (2) memberikan pengalaman pembelajaran kepada peserta didik; (3) melibatkan peserta didik dalam pembelajaran; (4) meningkatkan motivasi; (5) suasana belajara yang menyenangkan; (6) meningkatkan kemampuan pemecahan masalah; (7) membuat peserta didik menjadi lebih aktif; (8) meningkatkan kolaborasi; (9) memberikan dorongan bagi peserta didik dalam mengembangakan dan mempraktikkan keterampilan komunikasi. Tidak hanya ada kelebihan pada model project based learning ini, tetapi ada juga kelemahan dari model ini. Kekurangan yang ada pada pembelajaran berbasis proyek ini ialah memerlukan seorang pendidik yang berkompeten dan memiliki keinginan untuk belajar; memerlukan waktu serta biaya yang tidak sedikit; memerlukan sarana dan prasarana yang cukup memadai; model ini tidak sesuai dengan peserta didik yang mudah putus asa, tidak memiliki pengetahuan serta keterampilan; sukar apabila melibatkan peserta didik dalam kerja kelompok" (Niswara dkk., 2019:3).

Tahapan pelaksanaan model project based learning yang dilakukan pada kelas eksperimen yakni kelas VB dengan materi ekosistem. Ada tiga tahapan pelaksanaan model project based learning yang telah dilakukan yaitu tahapan pendahuluan, tahapan inti dan tahapan penutup. Dalam tahapan pendahuluan, diawali dengan memberikan pertanyaan medasar mengenai hubungan antar makhluk hidup di dalam ekosistem melalui google meet. Kemudian dilanjutkan dengan menentukan kegiatan yaitu membuat sebuah poster hubungan antar makhluk hidup di berbagai ekosistem. Siswa diberikan sebuah lembar petunjuk kegiatan serta alat dan bahan yang akan digunakan. Dalam membuat poster siswa diberikan waktu selama tiga hari. Selanjutnya pada tahapan inti, peneliti memantau pekerjaan siswa dalam membuat poster melalui whatsapp. Setelah poster selesai dibuat, hasil poster yang telah dibuat siswa diuji dengan meminta tiap-tiap peserta didik untuk mempresentasikannya. Kemudian pada tahapan terakhir, peneliti dan siswa bersama-sama merefleksikan kegiatan dan hasil poster yang telah selesai.

Penerapan model project based learning pada kelas eksperimen berjalan dengan baik, dapat dilihat bahwasannya penialian tara ratnaya bahkan dengan postest dengan demikian daya mampu siswa, materi dan menerapkan modelnya, bahkan dengan diterapkan di saat pembelajaran jarak jauh.

\section{KESIMPULAN}

Berdasarkan hasil penelitian dan pembahasan mengenai pengaruh project based learning berbantuan google meet terhadap kemampuan berpikir kreatif siswa materi ekosistem kelas V SD Negeri Pinang Ranti 01, menunjukkan bahwa hasil dari uji analisis independent $t$-test yaitu” $0,000<0,05$. Dengan demikian, terdapat pengaruh project based learning berbantuan google meet terhadap kemampuan berpikir kreatif siswa materi ekosistem kelas V SD Negeri Pinang Ranti 01. Project based learning dapat membantu peserta untuk mengembangkan serta meningkatkan kemampuan berpikir kreatif".

Pada masa pembelajaran daring ini, seyogyanya guru untuk berhati-hati dalam memilih model pembelajaran untuk digunakan dalam proses pembelajaran. Jika guru salah memilih, kemungkinan besar guru akan kesulitan dalam memberikan pengetahuan kepada siswa. Sehingga, siswa akan kesulitan ataupun pemahaman ataupuan ialah project based learning.

\section{UCAPAN TERIMA KASIH}

Peneliti berterimakasi kepada Allah SWT., keluarga serta para sahabat yang telah membantu dan memberikan semangat juga do'a. Tidak lupa pula, peneliti berterimakasih kepada pihak lainnya yang telah membantu dan memberikan kesempatan untuk peneliti dalam melaksanakan serta menyusun penelitian. Semoga kalian semua diberikan keberkahan dalam kehidupan.

\section{DAFTAR PUSTAKA}

Ahmad, A. (2017). Penerapan Permainan Bahasa (KATARIS) untuk Meningkatkan Keterampilan Membaca 
2383 Pengaruh Model Project Based Learning Berbantuan Google Meet terhadap Kemampuan Berpikir Kreatif Siswa - Aniswati Nahdiah, Sri Lestari Handayani

DOI: https://doi.org/10.31004/basicedu.v5i4.1228

Siswa Kelas IVA SD Negeri 01 Metro Pusat. EduHumaniora: Jurnal Pendidikan Dasar Kampus Cibiru, 9(2).

Ananda, R. (2019). Penerapan Metode Mind Mapping untuk Meningkatkan Kemampuan Kreatif Siswa Sekolah Dasar. Edukatif: Jurnal Ilmu Pendidikan, 1(1).

Haryadi, R., \& Selviani, F. (2021). Problematika Pembelajaran Daring di Masa Pandemi Covid-19. AoEJ: Academy of Education Journal, 12(2).

Hewi, L., \& Shaleh, M. (2020). Refleksi Hasil PISA (The Programme For International Student Assesment): Upaya Perbaikan Bertumpu Pada Pendidikan Anak Usia Dini). Jurnal Golden Age, 4(01).

Hikmah, L. N., \& Agustin, R. D. (2018). Pengaruh Model Pembelajaran Project Based Learning Terhadap Kemampuan Berpikir Kreatif Siswa. Prismatika, 1(1).

Ismail, F. (2018). Statistika: Untuk Penelitian Pendidikan dan Ilmu-Ilmu Sosial. Jakarta: Prenadamedia Group.

Juniartini, N. M. E., \& Rasna, I. W. (2020). Pemanfaatan Aplikasi Google Meet Dalam Keterampilan Menyimak dan Berbicara untuk Pembelajaran Bahasa Pada Masa Pandemi Covid-19. Pendidikan Dan Pembelajaran Bahasa Indonesia, 9(2).

Kusadi, N. M. R., dkk.. (2020). Model Pembelajaran Project Based Learning Terhadap Keterampilan Sosial Dan Berpikir Kreatif. Thinking Skills and Creativity Journal, 3(1).

Mawardi, \& Sari, P. A. P. (2019). Pengaruh Model Project Based Leraning Terhadap Kemampuan Berpikir Kritis IPA Siswa Kelas V Sekolah Dasar. Indonesian Journal of Elementary Education, 1(1).

Ningsih, S. (2014). Peningkatan Keterampilan Berbicara Melalui Metode Bercerita Siswa Kelas III SD Negeri 1 Beringin Jaya Kecamatan Bumi Raya Kabupaten Morowali. Jurnal Kreatif Tadulako Online, 2(4).

Niswara, R., dkk.. (2019). Pengaruh Model Project Based Learning Terhadap High Order Thinking Skill. Mimbar PGSD Undiksha, 7(2).

Nugraha, A. R., dkk. (2018). Penerapan Model Pembelajaran Project Based Learning (PjBL) untuk Meningkatkan Kreativitas dan Hasil Belajar IPA Pada Siswa Kelas 5 SD. Kalam Cendekia, 6(41).

Nuryati, D. W., dkk.. (2020). Pengaruh Project Based Learning Terhadap Kreativitas Peserta Didik di Masa Pandemi. Educate, 5(2).

Pratiwi, I. (2019). Efek Program PISA Terhadap Kurikulum Di Indonesia. Jurnal Pendidikan Dan Kebudayaan, $4(1)$.

Putri, F. P. W., dkk.. (2021). Perbedaan Model Problem Based Learning dan Project Based Learning Terhadap Hasil Belajar Siswa Sekolah Dasar. Edukatif: Jurnal Ilmu Pendidikan, 3(2).

Rustaman, A. H. (2020). Efektivitas Penggunaan Aplikasi Daring, Video Conference dan Sosial Media Pada Mata Kuliah Komputer Grafis 1 di Masa Pandemi Covid-19. Ilmu Sosial Dan Pendidikan, 4(3).

Sani, R. A. (2019). Pembelajaran Berbasis HOTS (Higher OrderThinking Skills). Kota Tangerang: Tira Smart.

Sari, S. P., dkk.. (2019). Penerapan Model Project Based Learning ( PjBL ) untuk Meningkatkan Kemampuan Berfikir Kreatif Peserta Didik. JP2EA: Jurnal Pendidikan Dan Pembelajaran Ekonomi Akutansi, 5(2).

Sitorus, A., \& Harahap, H. A. (2019). Gerakan Inovasi Mendidik Berkarakter. Lampung: Swalova.

Sudarto. (2016). Keterampilan dan Nilai Sebagai Materi Pendidikan Dalam Perspektif Islam. Al Lubab, l(1).

Sumarni, W. (2015). The Strengths and Weaknesses of the Implementation of Project Based Learning: A Review. International Journal of Science and Research (IJSR), 4(3).

Wiratama, N. A. (2020). Penerapan Google Meet Dalam Perkuliahan Daring Mahasiswa PGSD Pada Mata Kuliah Konsep Dasar PKN SD Saat Pandemi Covid 19. JTIEE, 4(2). 